In this issue:

Primary Sources for Understanding the New Copyright Law

ACRL Materials

News from the Field

Index

People

\title{
Primary Sources for Understanding the New Copyright Law
}

\section{By Hardy Carroll Assistant Professor, School of Librarianship Western Michigan University, Kalamazoo}

The new Copyright Law (P.L. 94-553), which is the first overall revision of U.S. copyright law since 1909 , was signed by President Ford on October 19, 1976. It will be completely in force starting January 1, 1978. Consequently, many librarians will be studying the new law this year to determine what changes in their present practices will be necessary to comply with it.

Librarians will probably be confronted with many interpretations of the new law this year, but all interpretations, if proper, are based mainly on four primary documents which are available to all citizens at no cost, as long as the supply lasts, from their U.S. senators or representatives. These primary sources, listed from the most recent to the oldest, are:

1. The new Copyright Law (P.L. 94-553). The text may be obtained as a slip law or as the final version of S.22 printed in the front of the "Conference Report" listed below.

2. The "Conference Report" (H.R. 94-1733) to accompany S.22. The report is dated September 29, 1976.

3. The "House Judiciary Committee Report" (H.R. 94-1476) to accompany S.22. The report is dated September 3, 1976. Corrections to this report are in the Congressional Record, September 21, 1976, p.H10727-28.

\section{The "Senate Judiciary Committee Report"} (S.R. 94-473) to accompany S.22. The report is dated November $20,1975$.

The law itself, P.L. 94-553, is the most important of these texts, but the reports are of special significance for the interpretation and legislative history of the law. Of the three committee reports, the "Conference Report" is the last and most authoritative. For example, it includes on pages 72-73 the guidelines for interlibrary photocopying developed by the National Commission on New Technological Uses of Copyrighted Works (the CONTU Guidelines), ${ }^{1}$ which largely supersede the examples of "systematic copying" given in the "Senate Judiciary Committee Report" on pages 70-71.

In reading these documents, the definitions at the beginning of each (Section 101 of the law) are basic. For example, "audiovisual works" do not include works that are only audio -the latter works are called "sound recordings" - whether the sounds are stored on phonograph records or on magnetic tape.

For considerations on the legality of photocopying copyrighted materials, the most important parts of the law are Sections 107 through 109. Section 107 is on "fair use." The new law is the first U.S. copyright law to have a provision for fair use of copyrighted works. Section 108 deals with the reproduction by libraries and archives that is allowed under the law in addition to fair use or inclusive of fair use.

1 These are reprinted in American Libraries 7:610 (Nov. 1976). 
A significant new provision is Section 108 (f) (1):

Nothing in this section . . . shall be construed to impose liability for copyright infringement upon a library or archives or its employees for the unsupervised use of reproducing equipment located on its premises: Provided, That such equipment displays a notice that the making of a copy may be subject to the copyright law.

For librarians who deal mainly with print and near-print materials, other interesting parts of the new law are:

Sections 102-105-The subject matter of copyright

Sections 302-305-Duration of copyright (The term of copyright has been changed to the life of the author plus fifty years.)

Section 501-Infringement of copyright

Sections 502-505-Remedies for infringement

Section 602-Infringing importation of copies or phonorecords (Photocopies of U.S. copyrighted items received from abroad, such as from the British Library Lending Division, are subject to the CONTU Guidelines.)

It will take some time-and much close study-before U.S. librarians and lawyers can determine what the new copyright law will mean to American library practices. But these four primary sources are the most authoritative places to begin.

A special issue of the ALA Washington Newsletter, November 15, 1976, presents a librarian's guide to the new copyright law and reproduces a substantial section from this new legislation, as well as from the various reports of congressional committees.

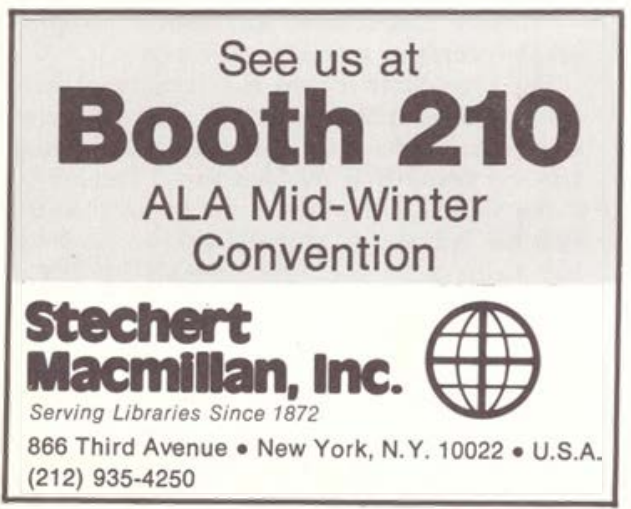

\section{Fulbright-Hays Exchange Program}

The Council for International Exchange of Scholars is now seeking candidates for a library science assignment at Cairo University under the 1977-78 senior Fulbright-Hays Exchange Program. Grantee will be asked to teach such courses as cataloging, reference, and library automation, as well as to advise on development of a curriculum for a Faculty of Information Science. In order to be considered, candidates must have U.S. citizenship, Ph.D. in library science, several years of teaching experience at the university level, and rank of assistant professor or above. Deadline-February 15. Application forms available from: Linda Rhodes, Senior Program Officer, Council for International Exchange of Scholars, 11 DuPont Circle, Washington, D.C. 20036. (Telephone: 202-833-4950).

News items for inclusion in C\&RL News should be sent to John $V$ Crowley Assistant Director of Libraries, Milne Library, State University College, Oneonta, NY 13820. Advertising (including classilied ads) should be sent to Leona Swiech, Advertising Olfice, American Library Association 50 E. Huron St. Chicago IL 606ll. Production and circulation matters are handled by ALA Central Production Unit, at the above address.

News editor: John V. Crowley, Assistant Director of Libraries, Milne Library, State University College, Oneonta, NY 13820. Editor: Richard D. Johnson, Milne Library, State University College, Oneonta, New York I3820. President, ACRL: Connie R. Dunlap. Executive Secretary, ACRL: to be announced.

College \& Research Libraries is published by the Association of College and Research Libraries. division of the American Library Association, 17 times yearly $\rightarrow$ bimonthly journal issues and 11 monthly (combining July-August) Nows issues-at I201-05 Bluff St., Fulton, MO 6525I. Subscription, $\$ 15.00$ a year, or to members of the division, \$7.50, included in dues. Second-class postage paid at Fulton, Missouri 65251

(1) American Library Assciation 1977. All material in this journal subject to copyright by the American Library Association may be photocopied for the noncommercial purpose of scientific or educational adrancement. 